\title{
DIAGNOSTIC POTENTIAL OF CALPROTECTIN FOR SPONTANEOUS BACTERIAL PERITONITIS IN PATIENTS WITHLIVER CIRRHOSIS AND ASCITES
}

\author{
Fana Lichoska Josifovikj ${ }^{1}$, Kalina Grivcheva Stardelova ${ }^{1}$, Beti Todorovska ${ }^{1}$, Magdalena Genadieva Dimitrova ${ }^{1}$, \\ Nenad Joksimovikj ${ }^{1}$, Vladimir Andreevski ${ }^{1}$, Meri Trajkovska ${ }^{1}$, Vladimir Serafimovski ${ }^{2}$ \\ ${ }^{1}$ University Clinical Centre Mother Teresa, Clinic for Gasteroenterohepatology, Faculty of Medicine, Ss. Cyril and Methodius \\ University in Skopje, R. North Macedonia \\ ${ }^{2}$ Macedonian Academy of Sciences and Arts
}

Corresponding author: Fana Lichoska Josifovikj, University Clinical Centre Mother Teresa, Clinic for Gasteroenterohepatology, Faculty of Medicine, Ss. Cyril and Methodius University in Skopje, R. North Macedonia, e-mail: fanili71@yahoo.com.

ABSTRACT

The development of spontaneous bacterial peritonitis (SBP) is a serious and life-threatening condition in patients with cirrhosis and ascites. The aim of this study was to determine the diagnostic potential of calprotectin in ascites, for SBP in patients with liver cirrhosis and ascites before and after antibiotic treatment and to compare the mean values of calprotectin in ascites in patients with and without SBP. This prospective-observational study was comprised of 70 patients with cirrhosis and ascites, divided into two groups, the SBP and the non-SBP group. Quantitative measurements of calprotectin in ascites was completed with the Quantum Blue Calprotectin Ascites test (LF-ASC25), using the Quantum Blue Reader. The average value of calprotectin in the SBP group was $1.5 \pm 0.40 \mu \mathrm{g} / \mathrm{mL}$, and in the non-SBP group it was lower $(0.4 \pm 0.30)$. The difference between the mean values was statistically significant with $\mathrm{p}<0.05$. The mean value of calprotectin in ascites before therapy among the SBP group was $1.5 \pm 0.4$, and after antibiotic therapy, the value decreased significantly to $1.0 \pm 0.6$; the difference between the mean values was statistically significant with $\mathrm{p}<0.05$. ROC analysis indicated that calprotectin contributed to the diagnosis of SBP with a $94.3 \%$ sensitivity rating (to correctly identify positives), and the specificity was $62.5 \%$, which corresponded to the value of 0.275 . Our research confirmed that ascitic calprotectin was a good predictor, and is significantly associated with the occurrence of SBP in patients with liver cirrhosis. By monitoring the value of calprotectin in ascites on the 7th day of antibiotic treatment, the effectiveness of antibiotic treatment in patients with SBP can be determined.

Keywords: spontaneous bacterial peritonitis (SBP), calprotectin, PMNC, liver cirrhosis

\section{INTRODUCTION}

The development of spontaneous bacterial peritonitis (SBP) is a serious and life-threatening condition in patients with cirrhosis and ascites. [1-3] The gold standard for the diagnosis of SBP is a polymorphonuclear cells (PMNC) number greater than or equal to 250 in $1 \mathrm{~mL}$ of ascites fluid. The PMNC count in ascites can be determined in two ways: by hematological methods with a microscope and a manual counting chamber or by an automatic cell counter. Microscopic cell counting takes several hours and carries the risk of errors that depend on the observer. On the other hand, automatic cell counters give fast results in minutes; but errors can occur here as well, especially 
in ascites with relatively low levels of neutrophils in ascites. Also, during transport to the laboratory, PMNC can be dissociated and can return false negative results. Ascites in patients with cirrhosis of the liver contains other components that may affect the outcome (dense viscous ascites). [4-7] For these reasons, several authors have suggested other alternative biomarkers for rapid diagnosis of SBP. $[8,9]$

\section{OBJECTIVE}

To determine the diagnostic potential of calprotectin in ascites, for SBP in patients with liver cirrhosis and ascites before and after antibiotic treatment and to compare the mean values of ascitic calprotectin in patients with and without SBP.

\section{MATERIAL AND METHODS}

In this prospective-analytical-observational study which was conducted at the University Clinic for Gastroenterohepatology in Skopje, 70 patients with cirrhosis and ascites were included, and they were divided into two groups. The division into groups was made according to the number of PMNC in the ascites. The first group included 35 patients with $P M N C \geq 250$ in $1 \mathrm{ml}$ of ascites fluid (SBP group) and the second group included 35 patients with PMNC $<250$ in $1 \mathrm{ml}$ ascites fluid (non-SBP group).

Patients included in the study were aged between 18 and 70 years. Exclusion criteria from the study were: acute liver failure, abdominal surgery in the last 3 months, infectious pleural effusion, peritoneal carcinomatosis, hemorrhagic ascites, hepatocellular carcinoma, and patients receiving antibiotics at least 2 weeks before enrollment.

After prior detailed information about the structure, content, and purpose of the study, patients were asked to sign the informed consent. The protocol of the study was in accordance with the ethical principles of the Declaration of Helsinki, and it was submitted, reviewed, and approved by the Ethics Commission of the Faculty of Medicine at the Ss. Cyril and Methodius University in Skopje.
Paracentesis was performed under aseptic conditions in a patient placed in a supine position and a puncture was made in the left or right lower quadrant of the abdomen with ultrasound imaging (none of the patients had complications associated with diagnostic paracentesis).

All diagnostic test specimens were immediately referred to the Central Clinical Laboratory. Out of a total of $20 \mathrm{~mL}$ of ascites, $5 \mathrm{~mL}$ was used for automatic PMNC counting, $5 \mathrm{~mL}$ for quantitative determination of calprotectin and $5 \mathrm{~mL}$ for biochemical analysis of ascites. At the same time, for the needs of biochemical blood tests, a venipuncture of $10 \mathrm{~mL}$ of blood was made. The PMNC number was determined directly from the non-centrifuged part of the ascites. $3 \mathrm{ml}$ of fluid was placed in an EDTA test tube to assess the total number of cells and PMN cells, and the counting was made by using the Sysmex KxN 21 automatic cell counter model.

Quantitative measurement of calprotectin in ascites was made with the Quantum Blue Calprotectin Ascites test (LF-ASC25), using the Quantum Blue Reader. Test principle: The test is designed to selectively measure the calprotectin antigen (MRP8 / 14) by direct sandwich immunoassay. The test membrane is coated with the first monoclonal antibody (mAb), which is specific for capturing calprotectin. The second monoclonal antibody conjugates calprotectin to colloidal gold and then releases it into the reaction system after the addition of a dilute ascites sample. Anti/calprotectin-gold-conjugated calprotectin binds to membrane-coated anti-calprotectin antibodies (test line; test strip), and the remaining free gold-conjugated anti-calprotectin binds to goat anti-mouse coated test membrane (control line; control strip).

The ascites samples were diluted with Chase Buffer in a ratio of 1:5 and after 12 minutes of incubation at room temperature, the signal intensity of the test line and the control line were quantified with the BÜLHLMANN Quantum Blue ${ }^{\circledR R}$ Reader. Procedure: Collected ascites samples were stored in sterile tubes in a refrigerator at a temperature of $-20^{\circ} \mathrm{C}$ without any chemical or biological additives.

Scanning started automatically after 12 minutes (720 seconds). The range of calprotectin concentrations in ascites ranged from $0.18 \mu \mathrm{g} /$ $\mathrm{mL}$ to $1.80 \mu \mathrm{g} / \mathrm{mL}$. Criteria for STDs: clinical picture, PMNC number in ascites $\geq 250 / 1 \mathrm{~mL}$ and / or PMNC number $<250$ / in $1 \mathrm{~mL}$ ascites 
fluid, with one bacterial species isolated in microbial culture (CNNA). The collected data were processed using the statistical program SPSS 20 and Statistica for Windows, version 10.

\section{RESULTS}

The average value of calprotectin in ascites in the SBP group was $1.5 \pm 0.40$, and in the non-SBP group it was lower $(0.4 \pm 0.30)$. The difference between the mean values was statistically significant with $\mathrm{p}<0.05$ (t-test $=12.70849$; $\mathrm{p}=0.000000)$ (Tab.1 and Fig 1,2).

Table 1. Average values of calprotectin in ascites in both groups and Student $t$-test, and calprotectin before and after therapy and Wilcoxon Matched Pairs test

\begin{tabular}{|c|c|c|c|c|c|c|}
\hline & $\begin{array}{l}\text { average } \\
\text { SBP }\end{array}$ & $\begin{array}{l}\text { average } \\
\text { non SBP }\end{array}$ & t-test & $\mathrm{p}$ & $\begin{array}{l}\text { SD } \\
\text { SBP }\end{array}$ & $\begin{array}{c}\text { SD } \\
\text { non SBP }\end{array}$ \\
\hline $\begin{array}{l}\text { calprotectin in ascites } \\
\text { before therapy }\end{array}$ & 1,6 & 0,34 & 16,42819 & 0,000000 & 0,404060 & 0,166926 \\
\hline $\begin{array}{l}\text { calprotectin in ascites } \\
\text { after therapy }\end{array}$ & 1,0 & & & & 0,611101 & \\
\hline \multirow{2}{*}{ Wilcoxon Matched Pairs-test } & & $\mathrm{T}$ & Z & p-value & & \\
\hline & & 5,000000 & 4,594930 & 0,000004 & & \\
\hline
\end{tabular}

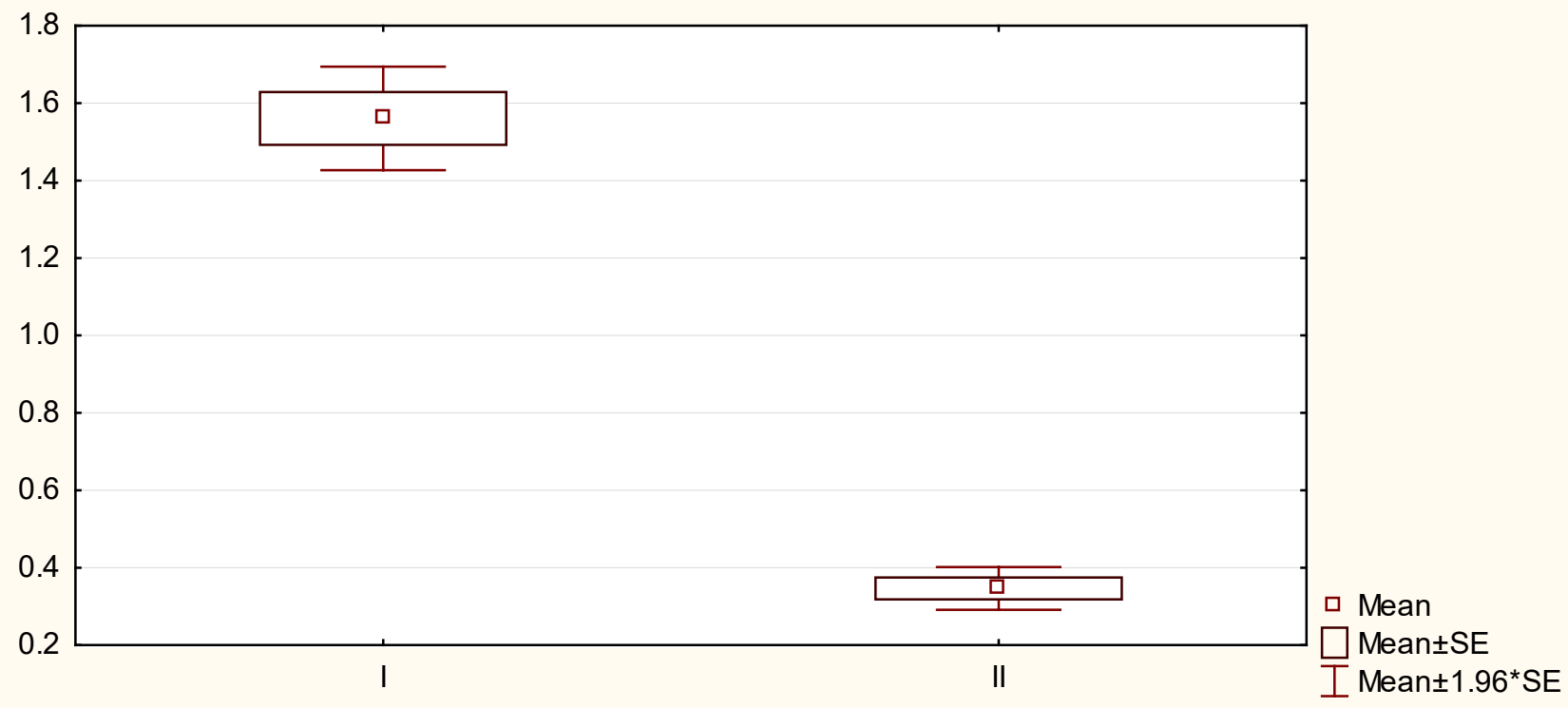

Figure 1. Average of calprotectin values in both groups.

The mean value of calprotectin in ascites before therapy in the SBP group was $1.5 \pm 0.4$, and after antibiotic therapy the value decreased significantly to $1.0 \pm 0.6$; the difference between the mean values was statistically significant with $\mathrm{p}<0.05$ (Wilcoxon Matched Pairs test, $\mathrm{T}$
$=5.00000 ; Z=4.594930 ; p=0.000004)(T a b .2$ and Fig 3, 4, 5).

ROC analysis indicated that calprotectin contributed to the diagnosis of spontaneous bacterial peritonitis at $89.5 \%(\mathrm{p}=0.044)$ (excellent predictor), closer to the ideal value of 1.0 and above the worst value of 0.5 (Table 2 and Figure 4).

According to the coordinates of the ROC curve for calprotectin, the sensitivity was $94.3 \%$ (to correctly identify positives), the specificity was $62.5 \%$, which corresponded to the value of 0.275 (cut off value) (Figure 4). The sensitivity of this parameter as a predictor was $94.3 \%$, and the specificity $62.5 \%$. 


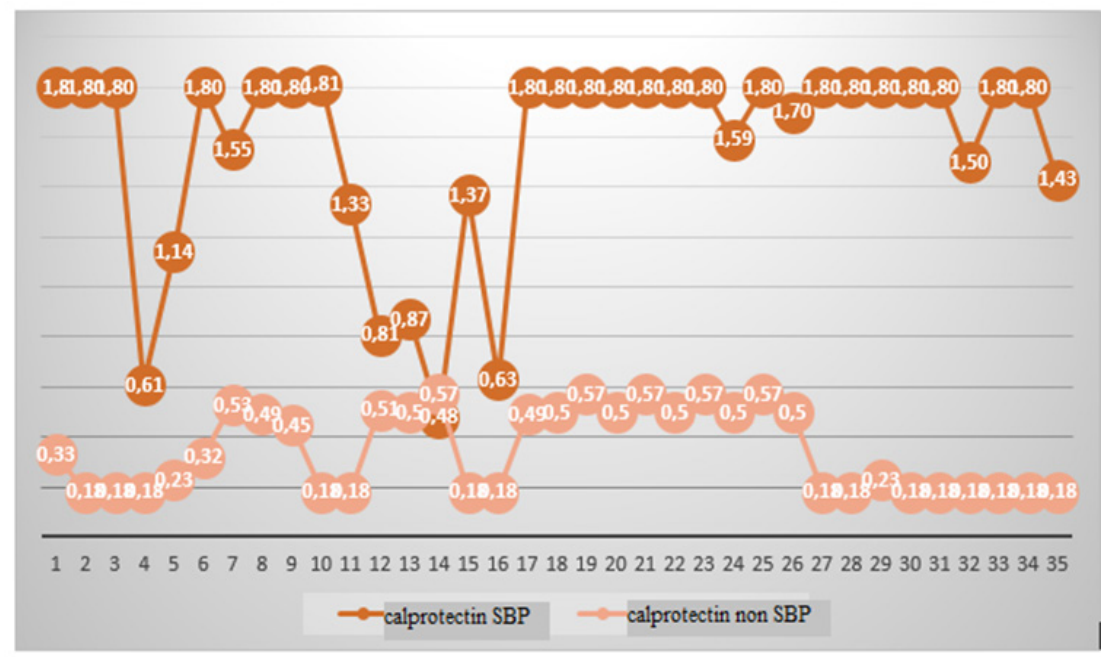

Figure 2. Movement of calprotectin in patients individually in SBP before and after therapy.

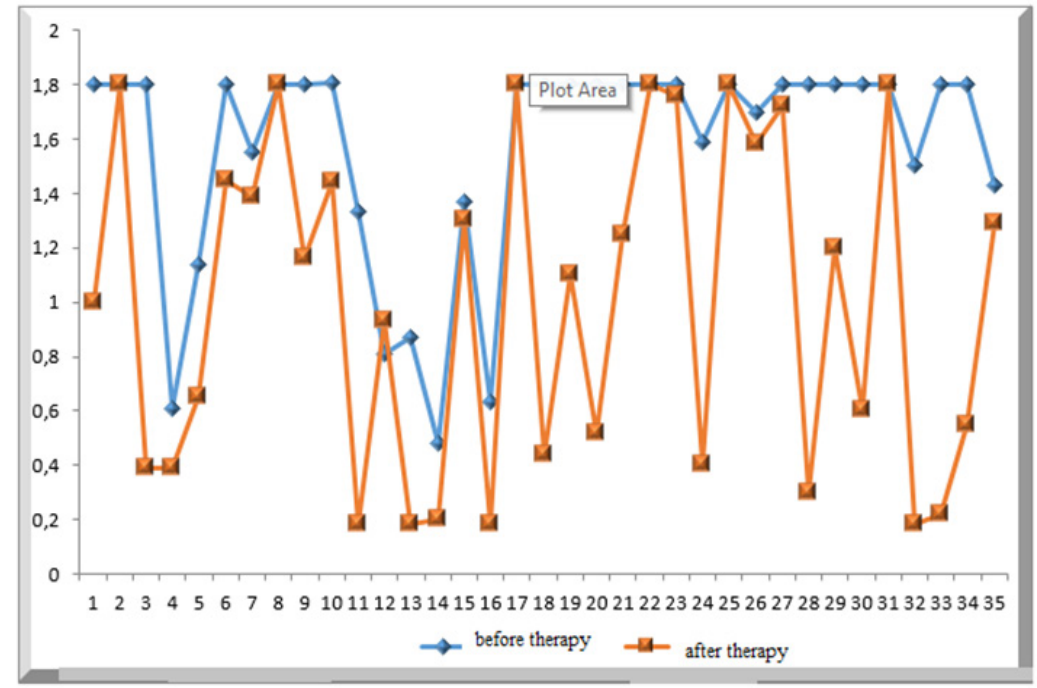

Figure 3. Display of mean calprotectin values in SBP before and after therapy

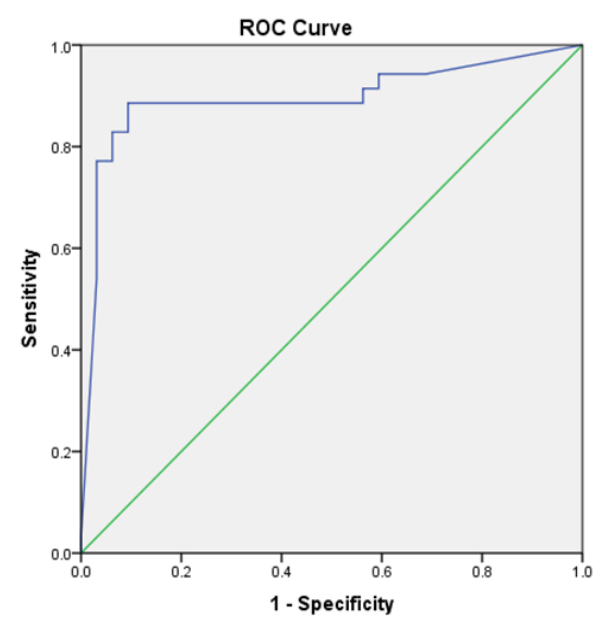

Diagonal segments are produced by ties.

Figure 4. ROC-curve of calprotectin as a predictor of $S B P$ 
nificant confirmed the correlation. The correlation was positive and direct, meaning that the increase of calprotectin after therapy increased the number of PMNC after therapy, and vice versa (Figure 6).

Table 2. Area Under the Curve

Area Under the Curve

\begin{tabular}{|l|r|r|r|r|}
\hline \multirow{2}{*}{ Area } & \multirow{2}{*}{ Std. Error } & \multirow{2}{*}{$\begin{array}{c}\text { Asymptomatic } \\
\text { Sig. }\end{array}$} & & \multicolumn{2}{|c|}{$\begin{array}{c}\text { Asymptomatic } 95 \% \text { Confidence } \\
\text { Interval }\end{array}$} \\
\cline { 4 - 5 } & & & Lower Bound & Upper Bound \\
\hline 0,895 & 0.044 & 0.000 & 0.808 & 0.981 \\
\hline
\end{tabular}

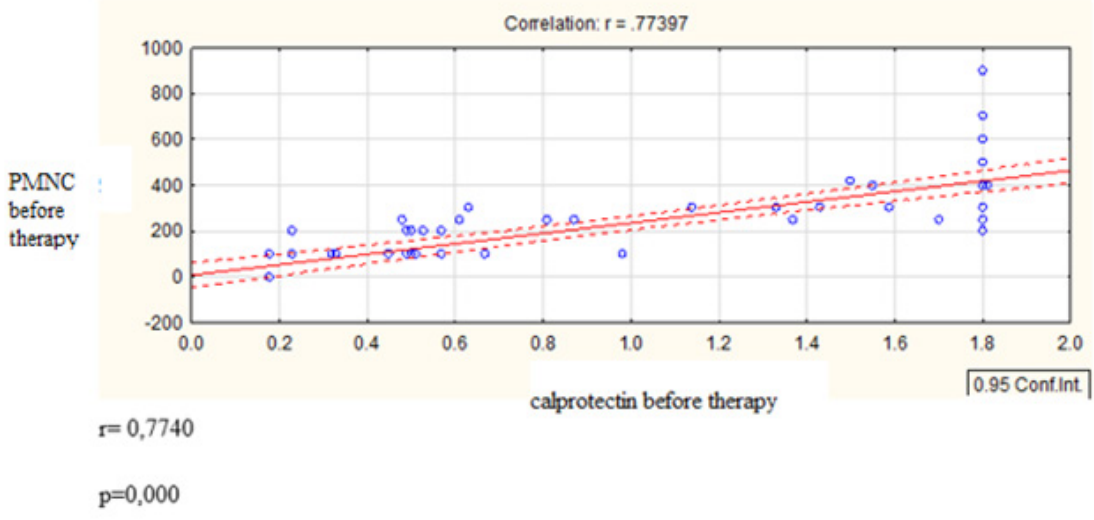

Figure 5. Pearson's linear correlation between calprotectin and PMNC before therapy.

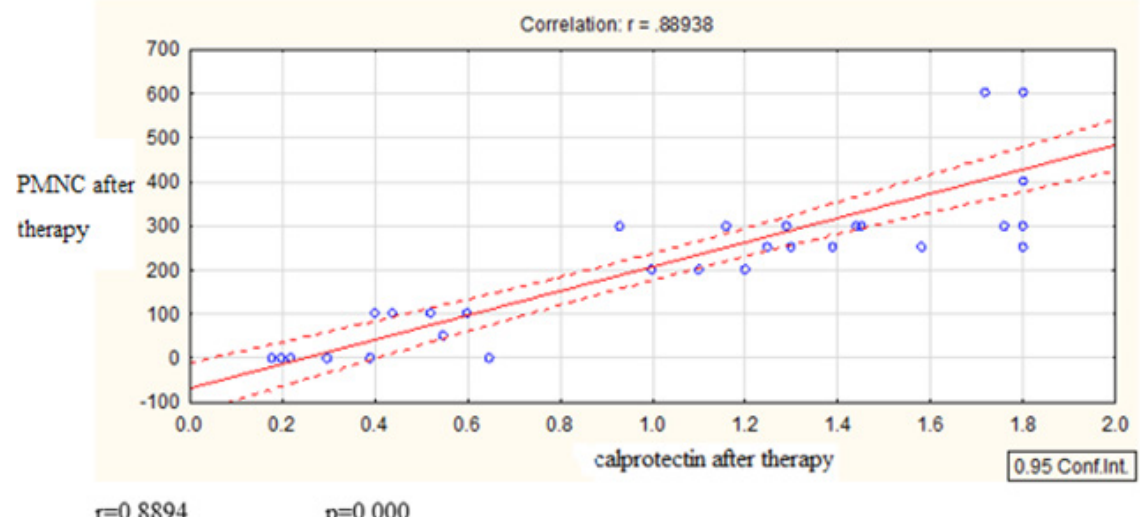

Figure 6. Pearson's linear correlation between calprotectin and PMNC after therapy. 


\section{DISCUSSION}

Over the last 20 years, the role of calprotectin as a non-invasive biomarker for the diagnosis of SBP has become increasingly important. The idea stems from its presence exclusively in neutrophils, which means that its value in body fluids is proportional to the influx of neutrophils. However, the number of studies addressing this issue is small despite promising and encouraging results, probably due to the relatively expensive method. Early publications by Homann et al. (10-12) examined the prognostic and diagnostic value of plasma calprotectin in patients with SBP.

The authors showed that patients with alcoholic decompensated liver cirrhosis, who had higher concentrations of calprotectin in ascites, were at increased risk of mortality. At the same time, calprotectin was shown to be a good marker for predicting SBP relapses. Its prognostic value was demonstrated by a multivariate analysis, showing that calprotectin had a much higher prognostic value for SBP than albumin, international normalized ratio (INR), bilirubin, and ascites, and did not depend on the severity of liver disease.

Three independent studies (13-15) examined the role of fecal calprotectin (FC) and its association with cirrhosis complications, hepatic encephalopathy (HE), and SBP. The results in all three studies showed higher concentrations of FC in patients with SBP versus controls $(\mathrm{P}<0.001)$, as well as a positive correlation of FC with HP according to the West-Haven criteria $(p<0.001)$. Burri et al. (16) in 2013 were the first who examined the correlation between calprotectin values in ascites and PMNC. In their prospective study, 130 samples of ascites were analyzed. Calprotectin was measured in $1 \mathrm{~mL}$ ascites by two biochemical methods: ELISA and point-of-care (POC) by Quantum Blue ${ }^{\circledR}$ Reader (Bühlmann Laboratories).

The results showed a positive correlation between PMNC and calprotectin for both tests (Spirman, $r=0.457$ for ELISA, $r=0.473$ for POC). Calprotectin concentrations detected by ELISA [median $0.43 \mu \mathrm{g} / \mathrm{mL}$, (IQR) 0.23-1.23 (range 0.10-14.93)] were similar to those of POC [median $0.38 \mu \mathrm{g} / \mathrm{mL}$, IQR 0.38-0.56 (range 0.38-13.31)]. Using the optimal cross-sectional value for ELISA $(0.63 \mu \mathrm{g} / \mathrm{mL})$, calprotectin in ascites had a sensitivity of $94.8 \%$, specificity of $89.2 \%$, positive and negative probability rates of 8.76 and 0.06 , positive and negative predictive value of $60.0 \%$ and $99.0 \%$ and a total accuracy of $90.0 \%$, while using the optimal cross-sectional value for POC $(0.51 \mu \mathrm{g} / \mathrm{mL})$, the corresponding values were $100.0 \%, 84.7 \%, 6.53 \%, 0.00 \%$, $52.8 \%, 100 \%$ and $87.7 \%$.

The author concluded that calprotectin in ascites can reliably predict $\mathrm{PMNC}>250 / \mu \mathrm{L}$, and can be used in the diagnosis of SBP. The same study showed a lower mean value of calprotectin in ascites compared to the mean value of calprotectin in our study. However, it should be noted that this study was composed of inhomogeneous groups (11 patients with malignant ascites and 4 patients with SBP) and it cannot be concluded that the published mean value is realistic for the diagnosis of SBP. Similar results were reported in a study by Abdel-Razik A et al. (9) with an average calprotectin ascites value of $0.445 \mu \mathrm{g} / \mathrm{ml}$.

Another prospective study [17] quantitatively measured calprotectin in ascites using POC with Bühlmann ${ }^{\circledR}$. The results of the study presented an optimal cut off value of calprotectin above $1.57 \mu \mathrm{g} / \mathrm{ml}$ with high sensitivity $(87.8 \%$ ), specificity (97.9\%) and positive $(97.3 \%)$ and negative $(90.2 \%)$ predictive values for diagnosing SBP.

A recent prospective study by Weil D. et al. [18] from 2018 evaluated the diagnostic significance of calprotectin concentration in ascites in SBP patients using the same laboratory method as we used in our study. The study registered a positive correlation between the values of calprotectin and PMNC ( $\mathrm{r}=0.57 ; \mathrm{p}<0.001)$. The optimal calprotectin threshold for the diagnosis of SBP was $1.51 \mu \mathrm{g} / \mathrm{mL}$ (with sensitivity, specificity, and positive and negative predictive values of $86.1 \%, 92.0 \%, 65.9 \%$, and $97.3 \%$, respectively). Our analysis recorded a strong, positive, statistically significant correlation between the value of calprotectin in ascites and PMNC (Pearson linear correlation $r=0.7740 \mathrm{p}=0.000$ ). 
The average value of calprotectin was $1.50 \mu \mathrm{g} /$ $\mathrm{mL}$, which was consistent with the value demonstrated in the study by Heikl AA et al. [19]

The level of calprotectin in ascites fluid was significantly correlated with PMNC and was higher in patients with SBP $(\mathrm{P}<0.001)$, with a cut-off value for SBP at $783 \mathrm{ng} / \mathrm{ml}$, with sensitivity, specificity, positive predictive value and negative predictive value and accuracy of $90 \%$, $1005,100 \%, 80 \%$ and $92.9 \%$, respectively. Similar results were presented in the studies of Fayrouz and Ali $(20,21)$. Our study also recorded a statistically significant difference between the mean values of calprotectin in ascites in patients with SBP versus non-SBP $(1.5 \pm 0.40$ vs. $0.4 \pm$ $0.30 ;$ t-test $=12.70849 ; \mathrm{p}=0.000000)$.

An analysis of individual variables confirmed that PMNC was a significant predictor of calprotectin levels in patients with SBP. For PMNC values, the partial regression coefficient was 0.68 , and the t-test showed that the PMNC effect of calprotectin was statistically significant at $p=0.000000$. If PMNC increases by one unit of measure, the value of calprotectin concentration increases by 0.687187 , on average. ROC analysis indicated that calprotectin is an excellent predictor for diagnosing SBP with $89.5 \%$ (p $=0.044)$ (excellent predictor), closer to the ideal value of 1.0 and above the worst value of 0.5 . According to the coordinates of the ROC curve for calprotectin, the sensitivity was $94.3 \%$ (to correctly identify positive), the specificity was $62.5 \%$, which corresponded to the value of 0.275 (cut off value).

Our multiple regression analysis recorded an association between calprotectin (dependent criterion variable) and a system of variables total protein in serum and ascites, serum and ascites CRP, PMNC, Child-Turcotte-Pugh II score, MELD score in patients when the multiple regression coefficient $(\mathrm{R})$ was 0.799 . The coefficient of determination (R2) was 0.64 and indicated that all independent variables together affected calprotectin by $64 \%$, while $36 \%$ were influenced by other factors.

The significance of the multiple regression coefficient test, based on the F-distribution, showed that the influence of the system of variables on calprotectin (dependent variable) in this group of patients with SBP was statistically significant for $p=0.00000$. Other studies with multiple regression analysis showed a positive correlation between the value of calprotectin in ascites with $\mathrm{PMNC}, \mathrm{C}$ - reactive protein (CRP) and total proteins in ascites $(\mathrm{P}<0.001, \mathrm{P}=0.036$ and $\mathrm{P}<0.001$ ), while a negative correlation was registered with age, etiology, sex, Child- Pugh and MELD scores as well as bacterial culture $(\mathrm{P}$ $=0.84 ; \mathrm{P}=0.41 ; \mathrm{P}=0.10, \mathrm{P}=0.86, \mathrm{P}=0.49$ and $\mathrm{P}=0.10) .[20,21,22]$

A pilot study [23] was published in 2020 to assess the probable factors predicting recurrence of SBP in patients recovering from the first episode of SBP, including patients with cirrhosis who did not receive secondary antibiotic prophylaxis for SBP. The study evaluated the values of the interferon-induced protein (IP-10), calprotectin, IL- 6 , and TNF- $\alpha$. A multivariate analysis showed IP-10 ( $\geq 1220 \mathrm{pg} / \mathrm{ml})$, calprotectin $(50550 \mathrm{ng} / \mathrm{ml})$, serum albumin $(\leq 2.5 \mathrm{~g} /$ dl), non-use of $\beta$-blockers, and use of a proton pump inhibitor (PPI) to be independent variables that can predict recurrence of SBP. The same author, in his retrospective cohort study, proposes a new, non-invasive scoring system (Mansoura) to confirm or exclude SBP. This system includes 4 variables: age (at least 55), mean $\operatorname{Tr}$ volume MPV (at least $8.5 \mathrm{fl}$ ), neutrophil-to-lymphocyte ratio NLR (at least 2.5), and CRP (at least $40 \mathrm{mg}$ /1). The scoring system is as follows: age, MPV and NLR are scored with 1 point each, while CRP with 2 points. Thus, a specificity of $98.2 \%$ is achieved with a positive predictive value for diagnosing SBP of 88.1\%. [24]

Previous studies have evaluated the efficacy and optimal duration of therapy in patients with SBP according to clinical criteria and by reducing the number of $\mathrm{PMNC}$ in ascites on the second day of therapy. [1, 25-28] However, a small number of studies have indicated possible errors (false low PMNC), resulting in higher mortality and higher recurrence rates of SBP. There is also evidence that not all SBP patients improve their clinical picture despite a reduced number of PMNC. [29-32] Therefore, we determined, in our study, the value of calprotectin in ascites before and after therapy. To our knowledge, there are no publications that determine the values of calprotectin in ascites before and after antibiotic treatment.

In our study, the average value of calprotectin in ascites before antibiotic therapy was $1.5 \pm 0.4$, and after antibiotic therapy a statistically significant decrease in value of $1.0 \pm 0.6$ was registered (Wilcoxon Matched Pairs test, T $=5,00000, Z=4.594930, p=0.000004)$. The 
obtained value of Pearson's linear correlation coefficient $(r=0.8894, p=0.000)$ showed that calprotectin after therapy correlated positively with the number of PMNC per therapy; the value of $p$ as statistically significant confirmed the correlation. The correlation was positive, i.e, direct, which means that the increase in calprotectin after therapy increased the number of PMNC after therapy, and vice versa.

\section{CONCLUSION}

Calprotectin in ascites can reliably predict PMNC $>250 / \mu \mathrm{L}$, and can be used as an alternative to other conventional methods for diagnosing SBP. By monitoring the value of calprotectin in ascites on the 7th day of antibiotic treatment, the effectiveness of antibiotic treatment in patients with SBP can be determined.

\section{REFERENCES}

1. Rimola A, García-Tsao G, Navasa M, Piddock LJ, Planas R, Bernard B, et al. Diagnosis, treatment and prophylaxis of spontaneous bacterial peritonitis: a consensus document. JHepatol 2000; 32: 142-53.

2. European Association for the Study of the Liver. EASL clinical practice guidelines for the management of patients with decompensated cirrhosis. J Hepatol 2018; 69(2): 406-460.

3. Runyon BA. Management of adult patients with ascites due to cirrhosis. AASLD Practice Guideline. Hepatology 2004; 39: 1-16.

4. Cereto F, Genescà J, Segura R. Validation of automated blood cell for the diagnosis of spontaneous bacterial peritonitis. Am J Gastroenterol 2004; 99: 1400.

5. Lutz P, Goeser F, Kaczmarek DJ, Schlabe S, Nischalke HD, Nattermann J, et al. Relative Ascites Polymorphonuclear Cell Count Indicates Bacterascites and Risk of Spontaneous Bacterial Peritonitis. Dig Dis Sci 2017; 62: 2558-2568 [PMID: 28597106 DOI: 10.1007/s10620-017-4637-4].

6. Reginato TJ, Oliveira MJ, Moreira LC, Lamanna A, Acencio MMP, Antonangelo A. Characteristics of ascitic fluid from patients with suspected spontaneous bacterial peritonitis in emergency units at a tertiary hospital. Sao Paulo Med J 2011; 129(5): 315-9.
7. Lee, HH, Carlson, RW, Bull, DM. Early diagnosis of spontaneous bacterial peritonitis: values of ascitic fluid variables. Infection 1987; 15: 232-6

8. Shizuma T. Spontaneous bacterial and fungal peritonitis in patients with liver cirrhosis: a literature review. World J Hepatol 2018; 10(2): 254-266.

9. Abdel-Razik A, Mousa N, Elhammady D. Ascitic fluid calprotectin and serum procalcitonin as accurate diagnostic markers for spontaneous bacterial peritonitis. Gut Liver 2016; 10: 624-631.

10. Homann C, Varming K, Hogasen K, Mollnes TE, Graudal N,Thomsen AC, et al. Acquired C3 deficiency in patients with alcoholic cirrhosis predisposes to infection and increased mortality. Gut 1997; 40: 544-549.

11. Homann C, Garred P, Graudal N, Hasselqvist Ph, Christiansen M, Fagerhol K.M, et al. Plasma calprotectin: a new prognostic marker of survival in alcohol-induced cirrhosis. Hepatology 1995; 21: 979-985.

12. Homann C, Christensen E, Schlichting P, Philipsen EK, Graudal NA, Garred P. Ascites fluid and plasma calprotectin concentrations in liver disease. Scand J Gastroenterol 2003; 38: 415-420.

13. Montalto M, Gallo A, Ferrulli A, Visca D, Campobasso E, Cardoneet S, al. Fecal calprotectin concentrations in alcoholic patients: a longitudinal study. Eur J Gastroenterol Hepatol 2011; 23: 76-80. doi: 10.1097/MEG.0b013e32834101f9.

14. Gundling F, Schmidtler F, Hapfelmeier A, Schulte B, Schmidt Th, Pehl Ch, et al. Fecal calprotectin is a useful screening parameter for hepatic encephalopathy and spontaneous bacterial peritonitis in cirrhosis. Liver Int 2011; 31: 1406-1415. doi: 10.1111/j.1478-3231.2011.02577.x.

15. Alempijević T, Štulić M, Popovic D, Culafic Dj, Dragasevic S, Milosavljevic T. The role of fecal calprotectin in assessment of hepatic encephalopathy in patients with liver cirrhosis. Acta Gastroenterol Belg 2014; 77: 302-305.

16. Burri E, Schulte F, Muser J, Meier R, Beglinger C. Measurement of calprotectin in ascitic fluid to identify elevated polymorphonuclear cell count. World J Gastroenterol 2013; 19: 2028-2036.

17. Fernandes SR, Santos P, Fatela N, Baldaia C, Tato marinho R, Proenca H, et al. Ascitic Calprotectin is a Novel and Accurate Marker for Spontaneous Bacterial Peritonitis. J. Clin Lab. Anal 2016; 30: 1139-1145.

18. Weil D, Heurgue-Berlot A, Monnet E, Chassagne S, Cervoni J-P, Feron T et al. Accuracy of calprotectin using the Quantum Blue Reader for the diagnosis of spontaneous bacterial peritonitis in liver cirrhosis. Hepatology Research 2018 doi: 10.1111/hepr.13239. 
19. Heikl AA, El-Nokeety MM, Roshdy E \& Mohey A. Ascitic calprotectin as a diagnostic marker for spontaneous bacterial peritonitis in hepatitis $\mathrm{C}$ virus cirrhotic Egyptian patients. Egypt J Intern Med 2018; 30: 1-7.

20. Selim FO, El-Deeb NA, Farrag HA \& Ahmed AM. Assessment of calprotectin in ascitic fluid as a marker for spontaneous bacterial peritonitis diagnosis in cirrhotic patients.ELM 2018, Volume: 30. Issue: 4; Page: 223-230.

21. Ali A G, Ahmed NS, Hasan SM. Calprotectin measurement in ascitic fluid: A new test for the rapid diagnosis of spontaneous bacterial peritonitis. Med. J. Cairo Univ 2013; 81(2): 53-56.

22. Rahman A, Attia FA, Alsebaey A, Elkady MAK, Sayed MM, Awad AR et al. Ascitic calprotectin as a useful marker in the diagnosis of spontaneous bacterial peritonitis in adults. Egyptian Liver J 2020; 10: 14.

23. Abdel-Razik A, Abdelsalam M, Gad DF, Abdelwahab A, Tawfik M, Elzehery R et al. Recurrence of spontaneous bacterial peritonitis in cirrhosis: novel predictors. European Journal of Gastroenterology \& Hepatology 2020; Volume 32 - Issue $6-$ p. $718-726$.

24. Abdel-Razik A, Mousa N, Abdel-Aziz M, Elsherbiny W, Zakaria S, Shabana W et al. Mansoura simple scoring system for prediction of spontaneous bacterial peritonitis: lesson learnt. European Journal of Gastroenterology \& Hepatology 2019; Volume 31 - Issue 8 - p. 1017-1024.

25. Tandon P, Garcia-Tsao G. Bacterial infections, sepsis and multiorgan failure in cirrhosis. Semin Liver Dis 2008; 28(1): 26-42.

26. Caruntu FA, Benea L. Spontaneous bacterial peritonitis: pathogenesis, diagnosis, treatment. J Gastrointestin Liver Dis 2006; 15: 51-56.

27. Runyon BA. Low-protein-concentration ascitic fluid is predisposed to spontaneous bacterial peritonitis. Gastroenterology 1986; 91: 1343-1346.

28. Angeloni S, Leboffe C, Parente A, Venditti M, Giordano A, Merli M, et al. Efficacy of current guidelines for the treatment of spontaneous bacterial peritonitis in the clinical practice. World $\mathrm{J}$ Gastroenterol 2008; 14: 2757-2762.

29. Castellote J, Girbau A, Ariza X, Salord S, Vazquez X, Lobaton T, et al. Usefulness of reagent strips for checking cure in spontaneous bacterial peritonitis after short-course treatment. Aliment Pharmacol Ther 2010; 31: 125-30.

30. Fong TL, Akriviadis EA, Runyon BA, Reynolds TB. Polymorphonuclear cell count response and duration of antibiotic therapy in spontaneous bacterial peritonitis. Hepatology 1989; 9: 423-426.

31. Ljubicic N, Spajic D, Vrkljan MM, Altabas V, Doko M, Zovak $\mathrm{M}$ et al. The value of ascitic fluid polymorphonuclear cell count determination during therapy of spontaneous bacterial peritoni- tis in patients with liver cirrhosis. Hepatogastroenterology 2000; 47: 1360-1363.

32. Cho JH, Park KH, Kim SH, Bang JH, Park WB, $\mathrm{Kim} \mathrm{HB}$, et al. Bacteremia is a prognostic factor for poor outcome in spontaneous bacterial peritonitis. Scand J Infect Dis 2007; 39: 697-702. 


\title{
Резиме
}

\section{ДИЈАГНОСТИЧКИ ПОТЕНЦИЈАЛ НА КАЛПРОТЕКТИНОТ ЗА СПОНТАН БАКТЕРИСКИ ПЕРИТОНИТИС КАЈ ПАЦИЕНТИТЕ СО ЦРНОДРОБНА ЦИРОЗА И АСЦИТ}

\author{
Фана Личоска Јосифовиќ ${ }^{1}$, Калина Гривчева Старделова ${ }^{1}$, \\ Бети Тодоровска ${ }^{1}$, Магдалена Генадиева Димитрова ${ }^{1}$, Ненад Јоксимовиќ ${ }^{1}$, \\ Владимир Андреевски ${ }^{1}$, Мери Трајковска', Владимир Серафимовски²
}

1 Универзитетски клинички центар Мајка Тереза, Клиника за гастроентерохепатологија, Медицински факултет, Св. Кирил и Методиј во Скопје, РС Македонија

${ }^{2}$ Македонска академија на науките и уметностите, РС Македонија

Развивањето на спонтаниот бактериски перитонитис (СБП) кај пациентите со црнодробна цироза и асцит е сериозна и животозагрозувачка состојба.

Целта на оваа студија беше да се одреди дијагностичкиот потенцијал на калпротектинот во асцит, за СБП кај пациентите со црнодробна цироза и асцит пред антибиотскиот третман и по него и да се споредат средните вредности на калпротектинот во асцитот кај пациентите со СБП и не-СБП. Оваа проспективно-опсерваториска студија беше составена од 70 пациенти со црнодробна цироза и асцит, поделени во две групи, СБП и не-СБП. Квантитативните мерења на калпротектинот во асцитот беа одредувани со Quantum Blue Calprotectin Ascites test (LF-ASC25), со помош на Quantum Blue Reader. Просечната вредност на калпротектинот во групата СБП беше 1,5 $\pm 0,40 \mu \mathrm{g} / \mathrm{mL}$, a во групата не-СБП беше помала $(0,4 \pm 0,30)$. Разликата меѓу средните вредности беше статистички значајна за $\mathrm{p}<0,05$. Просечната вредност на калпротектинот во асцитот пред терапијата кај групата СБП беше 1,5 \pm 0,4, а по терапијата со антибиотици, вредноста значително се намали на 1,0 \pm 0,6; разликата меѓу средните вредности беше статистички значајна за $\mathrm{p}<0,05$. ROC-анализата покажа дека калпротектинот придонел за дијагноза на СБП со чувствителност од 94,3 \% (за правилно да се идентификуваат позитивните случаи) и специфичност од 62,5%, што одговара на вредноста од 0,275. Нашето истражување потврди дека одредувањето на калпротектинот во асцит е добар предиктор и сигнификантно асоциран со појавата на СБП кај пациентите со црнодробна цироза. Следењето на вредностите на калпротектинот во асцитот седмиот ден од почетокот со третманот, може да ја утврди ефикасноста на антибиотскиот третман кај пациентите со СБП.

Клучни зборови: спонтан бактериски перитонитис (СБП), калпротектин, ПМНК, црнодробна цироза 